Recursos de relacionamento para profissionais de saúde: a boa comunicação com clientes e seus familiares em consultórios, ambulatórios e hospitais de Maria Tereza Maldonado e Paulo Canella. Rio de Janeiro: Reichmann \& Affonso Editores Ltda., 2003. 320 p.

\section{RESENHA DE LIVRO}

A presente obra é alicerçada na experiência dos autores na prática das relações estabelecidas entre 0 profissional e o cliente no contexto do trabalho em saúde. Tratado como guia para a atuação e reflexão do profissional, traz elementos para pensarmos o atendimento em saúde e suas vicissitudes.

A obra tem a autoria de Maria Tereza Maldonado, Mestre em Psicologia pela Pontifícia Universidade Católica do Rio de Janeiro, ex-professora da Pontifícia Universidade Católica do Rio de Janeiro e membro da American Family Therapy Academy. Seu parceiro na elaboração do livro é Paulo Canella, Livre-docente, Professor Titular de Ginecologia na Universidade Federal do Rio de Janeiro e Mestrado em Sexualidade pela Universidade Gama Filho.

Organizado em cinco partes, o livro trata 1 - "Infraestrutura do relacionamento: profissional e cliente como pessoas", 2 - "Formas típicas da comunicação", 3 - "Formas benéficas da comunicação", 4 - "Principais pontos do ciclo vital e as várias especialidades" e 5 - "Os profissionais e a instituição".

A construção do texto é baseada no referencial de base analítica, presente na abordagem dos tópicos trazidos para a discussão da temática, marcando a posição teórica dos autores, que defendem, a partir dessa lógica, a possibilidade de conceber no contexto do trabalho em saúde relações humanas mais eficientes, terapêuticas e sadias, tanto no que diz respeito às relações entre profissionais e clientes como dos profissionais entre si. A base em que se ancoram tais condições é denominada "chão do relacionamento", que significa a soma da gama de sentimentos e expectativas que envolvem a relação e o ambiente onde ele é processado.

No geral, o livro discute o papel do profissional de saúde, que é entendido como medicamento para o cliente pessoa, que deve ser compreendido em primeiro lugar como pessoa imersa em seus valores, idéias, opiniões. A atitude do profissional, na visão dos autores, pode ser tanto benéfica no processo de cura, como pode contribuir para a piora do quadro do cliente, daí a importância do mesmo em refinar-se como instrumento de trabalho.

$\mathrm{O}$ atendimento ao cliente é entendido como um encontro pessoal, único, que depende da sintonia profissional/cliente e das características institucionais onde ele se dá. O caráter de co-responsabilidade na relação é colocado como fator de ajuda para que a mesma aconteça de forma satisfatória, respeitando as assimetrias e diferenças presentes nas relações humanas. Esse é um aspecto relevante da obra, quando consideramos a discussão que tem sido feita no Brasil sobre a implantação de projetos de humanização nos serviços de saúde.

A questão da comunicação é tratada em grande parte do texto, onde são analisados os efeitos positivos e negativos desse processo nas situações cotidianas e, trazidos como exemplos, algumas possibilidades de aprofundamento do diálogo terapêutico. Tais tópicos pode ser úteis na discussão da temática em situações de ensino do relacionamento interpessoal.

As duas últimas partes do texto discutem as características e necessidades do atendimento às pessoas nas diferentes fases da vida e da formação de profissionais

\footnotetext{
${ }^{1}$ Doutor, Professor Titular, Pesquisador CNPq, e-mail: denize@fem.ufg.br; ${ }^{2}$ Professor Auxiliar, Mestranda do Programa de Pós-Graduação Mestrado em Enfermagem. Faculdade de Enfermagem da Universidade Federal de Goiás
} 
de saúde e sua inserção nas instituições, trazendo à discussão os desafios de adequar a formação dos profissionais aos novos tempos, do trabalho interdisciplinar e da utilização de recursos terapêuticos mais eficientes às necessidades dos clientes.

A análise feita sobre o contexto geral da obra é de um texto escrito em linguagem acessível, voltado para as questões do cotidiano no cuidado em saúde, cujo conteúdo envolve casos e exemplos que, embora não sejam amparados em resultados de pesquisa, nem se constituam propriamente em novidades sobre o tema, trazem outra roupagem à reflexão sobre atitudes e ações nos relacionamentos interpessoais no trabalho em saúde.

A discussão sobre a necessidade de mudança paradigmática na assistência em saúde e na formação de recursos humanos nessa área é a essência da obra, o que ressalta, de certa forma, a importância da produção do conhecimento de pesquisadores enfermeiros, que muito tem contribuído para a transformação da perspectiva do cuidado humano. 